\title{
Physiological Mechanisms Regulating Flower Abortion in Soybean
}

\author{
Makie Kokubun \\ Graduate School of Agricultural Science, Tohoku University \\ Japan
}

\section{Introduction}

Soybean yield is determined by the number of pods (seeds) produced per unit area and individual seed weight. The seed number depends upon the number of floral buds that initiate pods and attain maturity. Generally, soybean plants produce an abundance of floral buds, but a large proportion of them abort during development. Indeed, rates of flower and pod abscission/abortion were estimated to reach 80\% (Shibles et al., 1975). Alleviation of this abortion rate should increase pod and seed number, and thereby increase yield.

In a series of studies conducted in the 1950s and 1960s, Kato and his group examined abscised/aborted buds, flowers, and pods, and classified them according to their developmental stage. The greatest rate of abscission/abortion took place after fertilization, particularly during early stages of embryo development (Table 1). Based on this observation, they concluded that most critical stage causing flower abortion was at proembryo development after fertilization (Kato \& Sakaguchi, 1954; Kato et al., 1955; Kato, 1964). This important finding provided a basis for further anatomical and physiological analyses of the pod abortion process.

\begin{tabular}{|l|r|r|r|}
\hline & \multirow{2}{*}{$\begin{array}{c}\text { Days after } \\
\text { fertilization }\end{array}$} & \multicolumn{2}{|c|}{ Frequency of abortion (\%) } \\
\cline { 3 - 4 } Stage reached at failure & & 1952 & 1953 \\
\hline Flower differentiation & & 5.2 & 1.4 \\
Reproductive cell division & & 16.3 & 13.2 \\
Flowering (fertilization) & 0 & 4.3 & 3.6 \\
Initial phase of proembryo & $3-7$ & 43.3 & \\
Later phase of proembryo & $10-15$ & 12.8 & 81.8 \\
Cotyledon stage & $20-25$ & 17.9 & $\downarrow$ \\
\hline
\end{tabular}

Table 1. Frequencies of developmental stages of bud, flower and pod abortion at each developmental stage. Adapted from Kato \& Sakaguchi (1954) and Kato et al. (1955). Results from two years $(1952,1953)$ are shown. 
Subsequent studies conducted in the 1970s and 1980s suggested that soybean abortion is primarily caused by deficiency in or competition for photoassimilates and nutrients among growing organs (Brevedan et al., 1978; Brun \& Betts, 1984; Antos \& Wiebold, 1984). Shading treatment imposed at different reproductive growth stages clearly showed that reduced solar radiation significantly decreased the number of pods and seeds, and thereby grain yield (Kokubun, 1988). The yield reduction was particularly marked when the shading treatment was imposed during the period from flowering to early grain development, due to a decrease in dry matter production and/or dry matter partitioning to reproductive organs (Fig. 1).

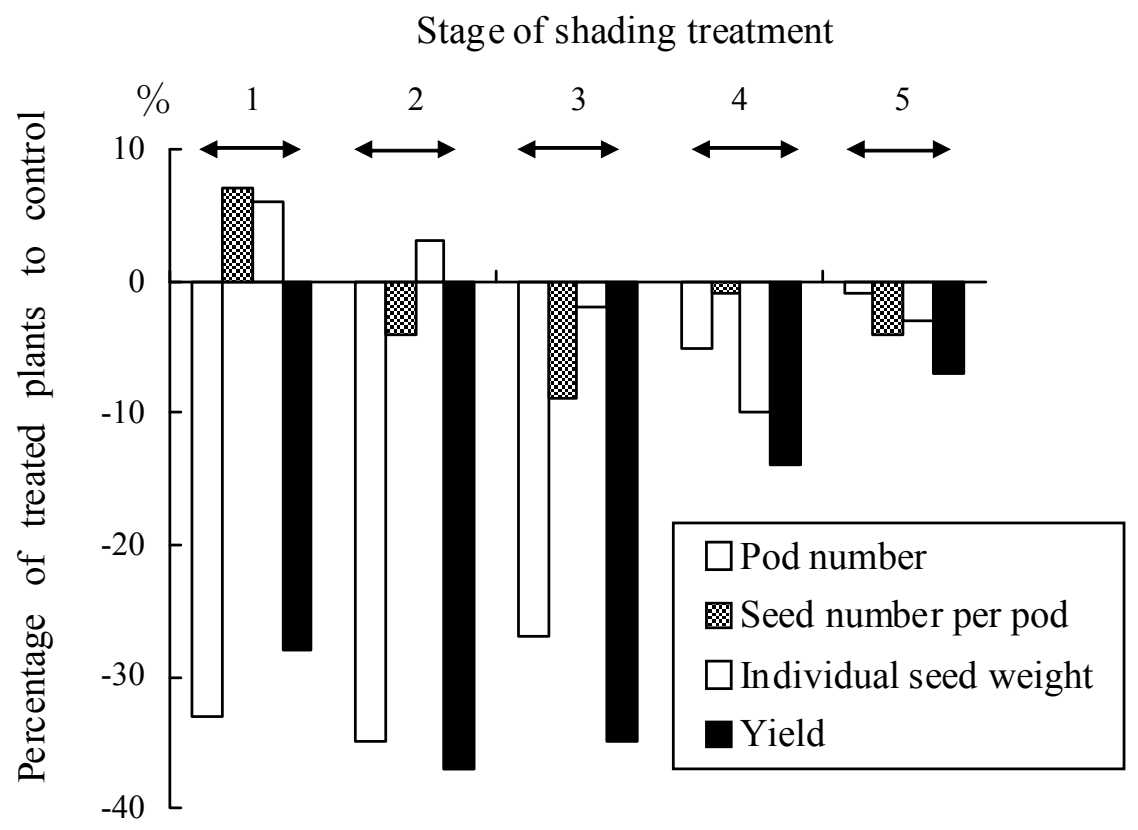

Fig. 1. Effects of 10-day shading treatment imposed at different reproductive growth stages. Stages of shading treatment: 1 Flowering, 2 Pod elongation, 3 Early pod-filling stage, 4 Middle pod-filling stage, 5 Late pod-filling stage. Cultivar: Raiden. Adapted from Kokubun (1988).

Water deficit during reproductive development was shown to be a dominant environmental factor accelerating the rate of abortion (Kato, 1964; Westgate \& Peterson, 1993). Based on these findings, Raper \& Kramer (1987) concluded that water stress imposed during flower development reduces photosynthesis and the amount of photoassimilates allocated to reproductive tissues, thereby accelerating the rate of abortion.

Another possible physiological factor affecting flower abortion in soybean is the availability of plant hormones (Huff \& Dybing, 1980; Heindl et al., 1982; Carlson et al., 1987). There are a number of reports showing that the application of 6-benzylaminopurine (BA) to racemes reduced the rate of abortion and thereby increased pod set. Analysis of endogenous cytokinins revealed that cytokinins detected in root pressure exudates showed a maximum 
concentration during a period from 0 to 9 days after initial flowering, when most flowers are destined to either initiate pods or abort (Heindle et al., 1982; Carlson et al., 1987).

Based on these previous findings, detailed mechanisms regulating the abortion have been under investigation since 2000. This chapter highlights major findings of our recent studies on these mechanisms, with an emphasis on 1) involvement of plant hormones in the occurrence of abortion, and 2) water stress as a factor affecting the abortion. A clarification of the mechanisms involved will promote the development of genetic or agricultural methods to alleviate pod abortion, leading to increased pod set and grain yield.

\section{Role of phytohormones in flower development in soybean}

\subsection{Evidence indicating the involvement of phytohormones in the regulation of flower development}

The critical role of phytohormones in the formation and abortion of reproductive organs in soybean was clearly recognized when Huff \& Dybing (1980) observed that extracts from flowers and young pods applied to growing flowers accelerated flower abortion. They then applied a lanolin paste containing either indoleacetic acid (IAA), giberellin (GA) or 6benzylaminopurine (BA) to the growing raceme, and found that IAA enhanced the abortion rate, as did the extract, whereas GA and BA did not. These results indicated that IAA plays a crucial role in increasing the abortion rate, although there was a conflicting report indicating that IAA delays the abortion (Oberholster et al., 1991).

\subsection{Cytokinin as a key hormone regulating pod development}

Among phytohormones, cytokinins are considered to play a vital role in floral development in soybean. There have been numerous reports showing that the application of BA to racemes reduced seed abortion and increased pod number (Crosby et al., 1981; Carlson et al., 1987; Dyer et al., 1987; Peterson et al., 1990; Mosjidis et al., 1993; Reese et al., 1995; Nagel et al., 2001). A limited number of reports support the notion that cytokinins are produced by the root system and transported to the shoot, where they are involved in the regulation of shoot development (Sitton et al., 1967; Wareing et al., 1968). To examine the hypothesis that cytokinins produced in the root system are transported to the shoot, Heindle et al. (1982) collected root pressure exudates from detopped roots, and analyzed the forms and quantities of cytokinins in these exudates. Using high-performance liquid chromatography, they isolated and quantitated several forms of cytokinins: zeatin, zeatin riboside, and their dihydro derivatives, dihydrozeatin and dihydrozeatin riboside. Their results indicated that cytokinin fluxes were independent of exudate flux, and that the ribosides accounted for the majority of the observed transport. In a later study, they also found a peak in cytokinin concentration during the period from the beginning of anthesis until 9 days after initial anthesis (Heindl et al., 1982; Carlson et al., 1987). This period corresponds to a stage in which most flowers are destined to either initiate or abort floral structure. Based on these findings, they concluded that cytokinins exported from the root may function in the regulation of reproductive growth in soybean.

\subsection{Relationship between intra-raceme variation in pod-set probability and cytokinin concentrations}

The magnitude of the rate of flower abortion was observed to vary with the position on the plant. For example, it was higher in the branches, in the lower part of the main stem and in 
the top nodes of the main stem (Hansen \& Shibles, 1978; Wiebold et al., 1981; Heindl \& Brun, 1983, 1984; Gai et al., 1984). Within individual racemes, flowers on the distal portions on the rachis exhibited a higher probability of abortion than did those on the basal portions (Huff \& Dybing, 1980; Spollen et al., 1986a, 1986b; Dybing et al., 1986; Carlson et al., 1987; Wiebold, 1990; Wiebold \& Paciera, 1990).
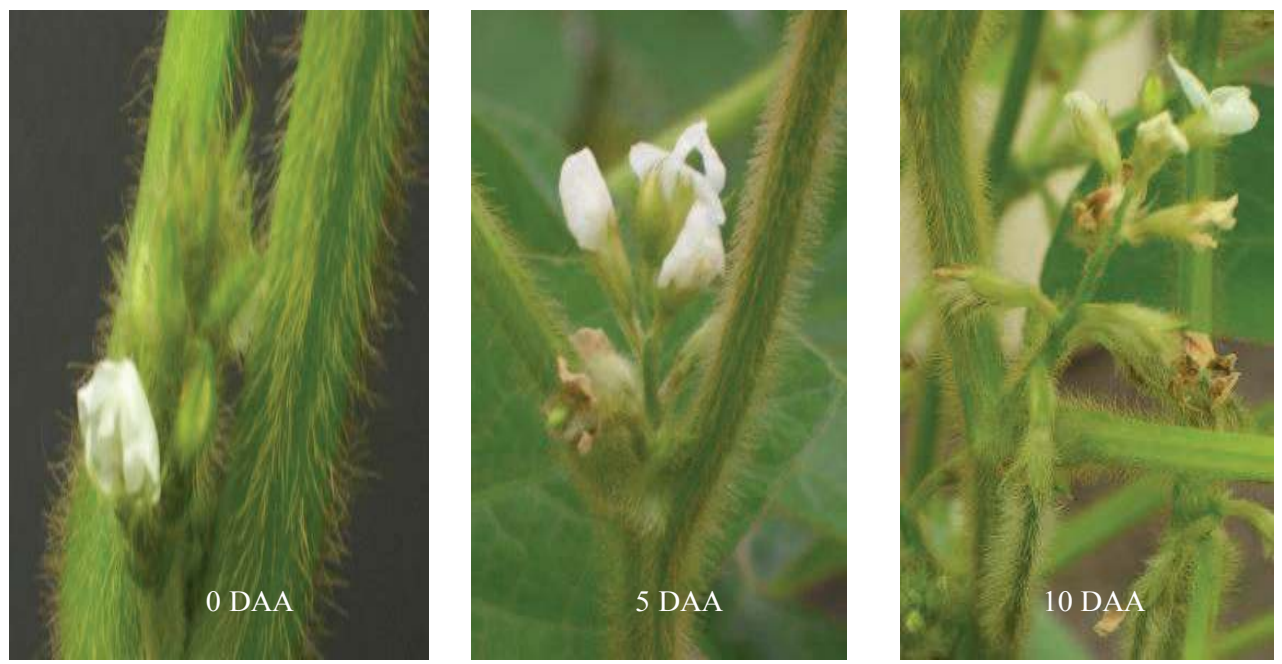

Fig. 2. Development of pod after flowering. Genotype: IX93-100. DAA, Days after anthesis of first flower in raceme. Photo by Nonokawa.

As described above, the role of cytokinins in promoting development of floral structures in soybean had been clarified by several studies (Huff \& Dybing, 1980; Heindl et al., 1982; Carlson et al., 1987). However, the nature of ontogenetic changes in the cytokinin content of racemes, and the relationship between the location of cytokinin on the plant and pod abortion remained unknown until 1990s. For precise analyses of intra-raceme variation in pod set and cytokinin contents, soybean genotype IX93-100, which has long racemes (approximately $10 \mathrm{~cm}$, depending on the environmental conditions), was used as plant material. The developmental stages of this genotype are shown in Fig. 2.

We examined the ontogenetic changes in cytokinins detected in different portions in racemes to determine whether a relationship exists between cytokinin concentration and pod-set probability at a specific floral position on a raceme (Kokubun \& Honda, 2000). In an experiment using genotype IX93-100 grown in an environmentally controlled chamber $\left(30 / 20^{\circ} \mathrm{C}\right.$ day/night temperature, $15 \mathrm{~h}$ day length, $600 \mu \mathrm{mol} \mathrm{mol}-2 \mathrm{~s}^{-1}$ photosynthetic photon flux density (PPFD)), we found that the total amount of cytokinin in racemes peaked one to two weeks after the first flowering event on a raceme, when pod development initiated. Within individual racemes, the total amount of cytokinin was greater at more proximal floral positions, as was the probability of pod set (Fig. 3). Removal of proximal flowers increased both cytokinin content and pod-set probability at middle positions on the raceme. Thus, cytokinin content in racemes was closely associated with pod-set probability within individual 
racemes. Each flower on a raceme initiated a pod 4 to 7 days after anthesis. During this period, a fertilized ovule develops embryo and endosperm, and cells are dividing actively (Carlson \& Lersten, 1987). Microscopic observation showed that most of the abscised flowers are in the proembryo stage, which occurs several days after anthesis (Kato, 1964; Abernethy et al., 1977). Abernethy et al. (1977) speculated that the frequent occurrence of abscission at this stage was due to the reduced level of a cell division mediating factor.

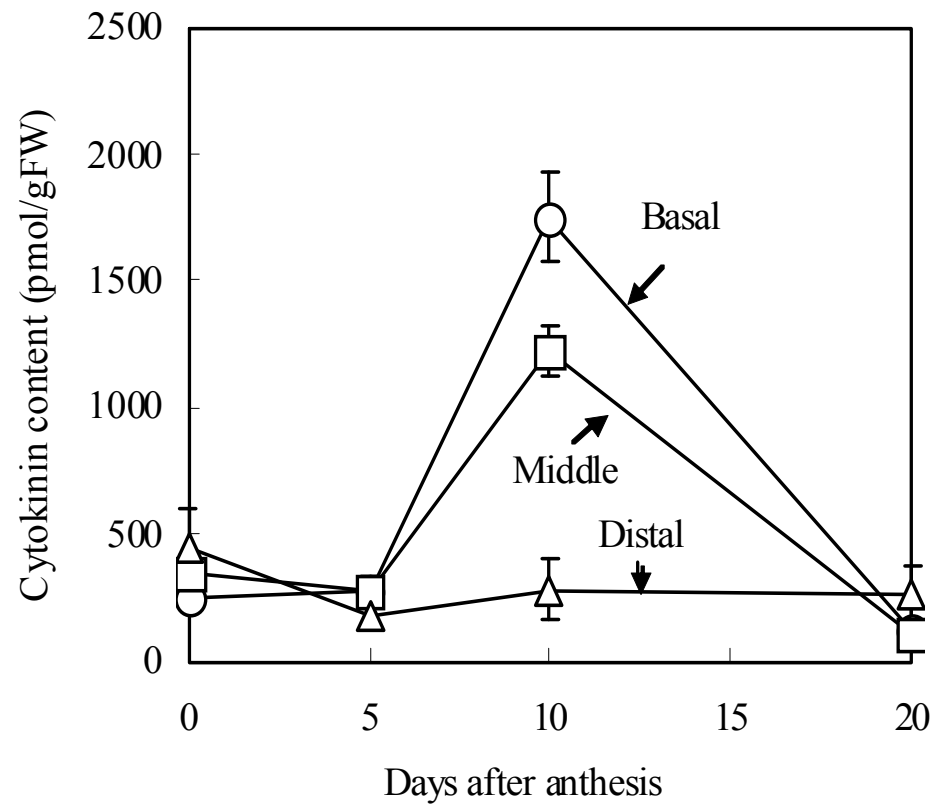

Fig. 3. Changes in the amount of cytokininis in various portions (basal, middle and distal) of racemes during reproductive development in soybean. Portions: 1-3 (basal), 4-6 (Middle), and 7 and above (Distal), numbered from the most basal portion on the rachis. Adapted from Kokubun \& Honda (2000).

The biosynthetic pathway for cytokinins has not been fully elucidated in soybean. In our study, the dominant forms of cytokinins were identified to be cis-zeatin riboside (c-ZR) and isopentenyladenosine (iPA), which differed from the forms detected in exudates previously reported by Heindl et al. (1982) and Carlson et al. (1987). In chickpeas, cis-isomers were found to be predominant in seeds (Emery et al., 1998), while trans-isomers are the more commonly reported forms in higher plants (McGaw \& Burch, 1995; Prinsen et al., 1997). Further studies are currently in progress to identify the forms of cytokinins detected both in exudates and racemes in our laboratory.

\subsection{Effects of cytokinin application in plants with varying source-sink ratios}

The clear evidence that cytokinin plays a prompting role in flower development raised the following question. Does cytokinin accelerate flower development independently or synergistically with photoassimilate supply? To address this question, we examined the combined effects of these two physiological circumstances by manipulating source-sink 
ratios at specific nodes in soybean plants (Yashima et al., 2005). As the source-sink ratio increased, the number of pods per node on manipulated plants increased curvilinearly, reaching a plateau at high source/sink ratios. By contrast, when cytokinin was also applied to the nodes, the number of pods per node increased with increasing source/sink ratio with no plateau, either through an increase in the number of flowers or through an increase in the pod-set probability, depending on the year (Fig. 4). These results indicate that cytokinin plays an augmenting role in pod number increase for plants with high levels of assimilate availability. In another experiment in which synthetic cytokinin (6-benzylaminopurine) was introduced into the xylem stream through a cotton wick during anthesis, Nagel et al. (2001) found that the effect of cytokinin application on pod number and seed yield was consistently significant in the greenhouse, but it was variable in the field. These findings suggest that increased supplies of cytokinins produced in roots and translocated to racemes are able to accelerate pod development in plants with high source/sink ratios, but that the positive effect of cytokinins on flower development can vary with environmental factors.
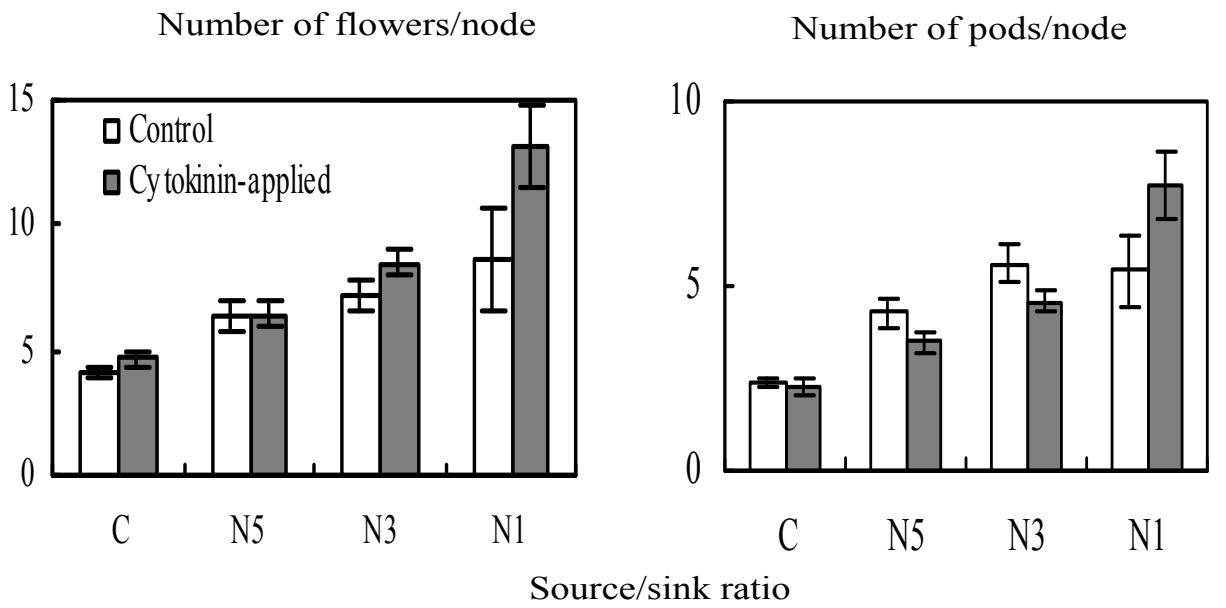

Fig. 4. Effects of source/sink ratio and cytokinin application on the number of flowers per node and the number of pods per node. Values represent the mean \pm SE of six plants. C: Control. N5, N3 and N1: Nodes five, three and one node, respectively were allowed to bear racemes. Adapted from Yashima et al. (2005).

As indicated above, the significant effects of cytokinin and IAA application were observed only in pot-grown plants, but their effects were obscured in field-grown plants (Cho et al., 2002; Nonokawa et al., 2007). This instability in the effects of hormones application to fieldgrown plants may be ascribed to climatic variation across years. Therefore, the specific climatic conditions in which hormones, particularly cytokinins, enhance pod set should be examined to optimize the agricultural use of cytokinins in the field.

\subsection{Combined effects of multiple phytohormones on the regulation of flower development}

Plant hormones often do not act alone, but in conjunction with or in opposition to each other in such a manner that the final state of plant development reflects the net effect of the 
interplay of two or more hormones. Regarding the effects of hormones other than cytokinins on soybean floral development, there have not been many studies (Huff \& Dybing, 1980; Oberholster et al., 1991). Views on the role of IAA were conflicting, which could be a reflection of genotypic or cultural differences in those experiments.

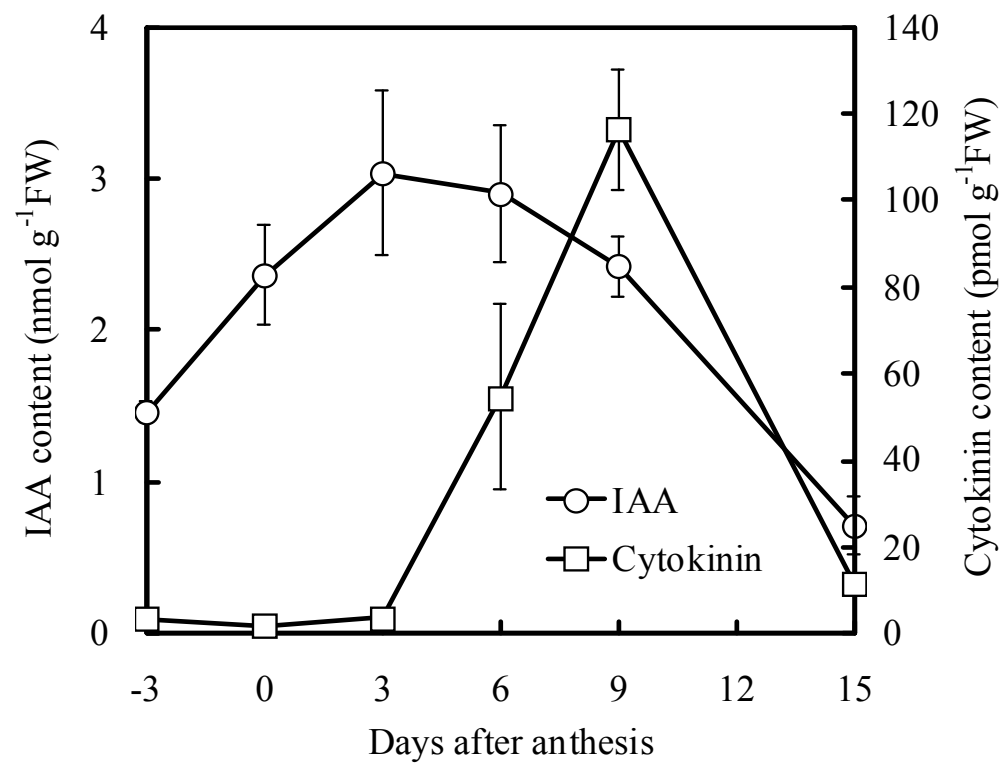

Fig. 5. Changes in the endogenus concentration of IAA and cytokinin ( $t$-ZR equivalent) in racemes during reproductive development of soybean plant. Racemes were sampled for analysis at intervals before and after anthesis. Values represent the mean $\pm \mathrm{SE}(n=6)$. Adapted from Nonokawa et al. (2007).

Using the same plant material (IX93-100) grown in pots and in the field, we examined changes in the concentrations of endogenous auxin and cytokinin within racemes and the effects of application of the two hormones on pod set. The auxin (IAA) concentration in racemes was high for a long period from pre-anthesis to ca. 10 days following the anthesis (DAA) of the first flower on a raceme, but the cytokinin concentration remained elevated for a shorter period, with a peak at 9 DAA (Nonokawa et al. (2007) (Fig. 5). The two phytohormones are located primarily at different positions within a raceme; the IAA concentration was higher in distal portion of racemes, whereas the cytokinin concentration was higher in basal portions of racemes. IAA application to racemes reduced the number of flowers and pods throughout the reproductive stage. In contrast, the effect of cytokinin (BA) application varied depending on the growth stage: application of BA at around 7 DAA significantly increased the pod-set percentage, while at other stages BA application reduced pod set. Thus, the concentrations of the two endogenous hormones changed in a different manner, with cytokinins exerting a positive effect, and auxin exerting a negative effect on pod set, depending on the growth stage. 


\section{Difference in susceptibility to water stress between male and female structures}

\subsection{Water stress as a factor increasing the abortion}

Deficient water supply during reproductive development is a major environmental factor that increases the rate of pod abortion in soybean (Kato, 1964; Westgate \& Peterson, 1993). While the effect on yield of increased pod abortion at one stage can be offset an increase in pod set at another stage of development, or by an increase in seed mass, frequent or longterm water deficit during reproductive development reduces the yield of soybean (Shaw \& Laing, 1966; Sionit \& Kramer, 1977). In fact, the rate of abortion substantially increases when soybean plants are subjected to water deficient conditions during reproductive development, particularly during later flowering stages. Water stress imposed during flowering and early pod development reduces photosynthesis and the amount of photosynthetic assimilates allocated to floral structures, which is likely to increase the rate of abortion (Raper \& Kramer, 1987). These findings raise the following question. Does water deficit prior to flowering impair the development of male or female structures?

\subsection{Differences between pollen and ovule in susceptibility to water stress}

To address the above question, we conducted experiments to clarify a) whether water deficit imposed on a soybean plant prior to flowering caused abortion of the basal flowers on the rachis, which are very likely to develop seed-bearing pods under favorable conditions, and b) whether the abortion, if occurred, was due to the impairment of stamen (pollen) or pistil (ovule) function (Kokubun et al., 2001; Kokubun, 2004). IX93-100 plants were grown for this experiment in controlled environment chambers $\left(30 / 20^{\circ} \mathrm{C}\right.$ day/night temperature, $60 \pm 10 \%$ relative humidity, $15-\mathrm{h}$ photoperiod at $600 \mu \mathrm{mol} \mathrm{m} \mathrm{m}^{-2} \mathrm{~s}^{-1}$ PPFD on the plant canopy). Plants were irrigated frequently to maintain soil moisture at $70 \%$ of the water-holding capacity of the soil, except during periods of experimental restriction of the water supply. When plants began to flower, the water supply was restricted to a level at which the water potential of the leaves fell below $-1.5 \mathrm{MPa}$. This treatment was imposed on half of the plants and lasted for three days, then plants were rewatered to the original moisture level. After the water restriction treatment was initiated, well-watered (WW) and water-deficient (WD) plants were reciprocally hand pollinated $(\mathrm{WW} \times W D$ and $W D \times W W)$ daily for 10 days. Water stress caused by restriction of watering for three days during the pre-anthesis stage significantly increased the abortion of the basal flowers, which are destined to develop into pods under optimal irrigation (Fig. 6). The experiment also revealed that the pistils of well-watered plants, whether pollinated with water-stressed or unstressed pollen, produced pods at a considerable rate, whereas only a small percentage of water-stressed pistils developed into pods, even when crossed with unstressed pollen (Fig. 7).

In soybean, water deficiency decreased leaf water potential $\left(\phi_{\mathrm{w}}\right)$, resulting in decreased photosynthesis when the leaf $\phi_{\mathrm{w}}$ was below -1.1 MPa (Boyer, 1970). In our experiment, the leaf $\phi_{\mathrm{w}}$ of water-deficient plants fell below -1.1 MPa for several days, and photosynthetic rates of the stressed leaves were substantially lower than those of well-watered plants. A decrease in photosynthetic rate may have reduced photoassimilate allocation to reproductive organs, which could have increased the rates of flower abortion in waterdeficient plants, particularly during the period from one to four days after the initiation of the water restriction treatment. However, after the leaf $\phi_{\mathrm{w}}$ of the water-deficient plants recovered to the control level after rewatering, the photosynthetic rates also recovered. 

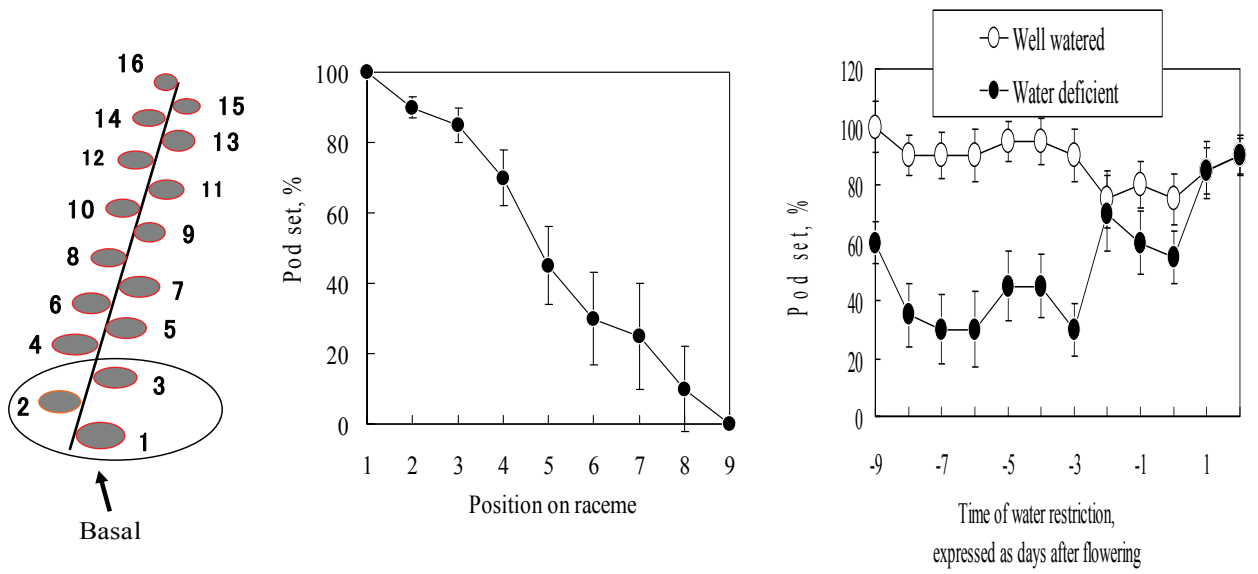

Fig. 6. Pod-set percentage of flowers at different positions in a raceme, and the effect of water restriction on pod-set percentage of flowers located on the basal portion of the raceme. Left: flowers numbered from basal portion on rachis. Center: Pod-set percentage of flowers at different positions on a raceme of well-watered plants. Right: pod-set percentage of well-watered plants and water-deficient plants which were subjected to water restriction treatment for three days imposed for three days prior to flowering. Adapted from Kokubun et al. (2001).

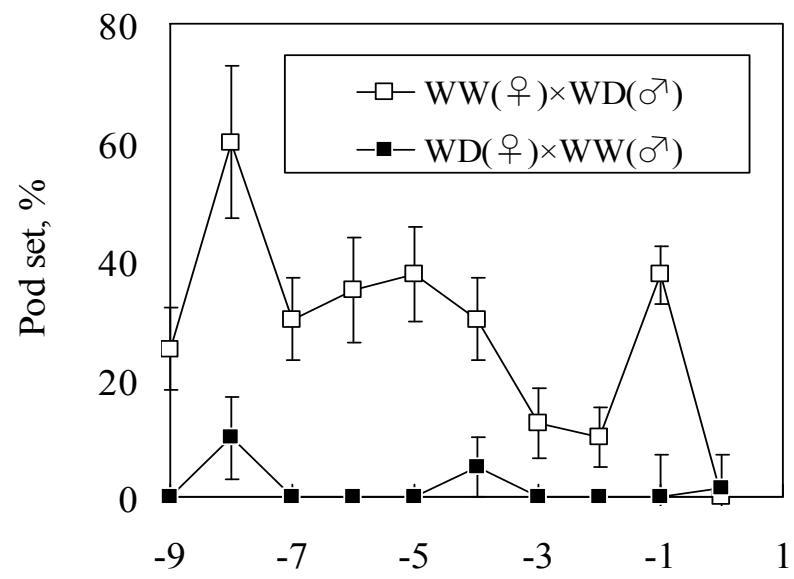

Time of water restriction, expressed as days after anthesis

Fig. 7. Pod-set percentage of hand pollinated flowers that were reciprocally crossed between well-watered (WW) and water-deficient (WD) plants. From Kokubun et al. (2001).

Despite the recovery of leaf $\phi_{\mathrm{w}}$ and photosynthetic rates within a few days following rewatering, the water-deficient plants exhibited significantly lower pod-set percentage than the well-watered plants. This evidence suggests that the decreased pod-set percentage might be caused by factor(s) other than a reduction of photosynthetic assimilation. 


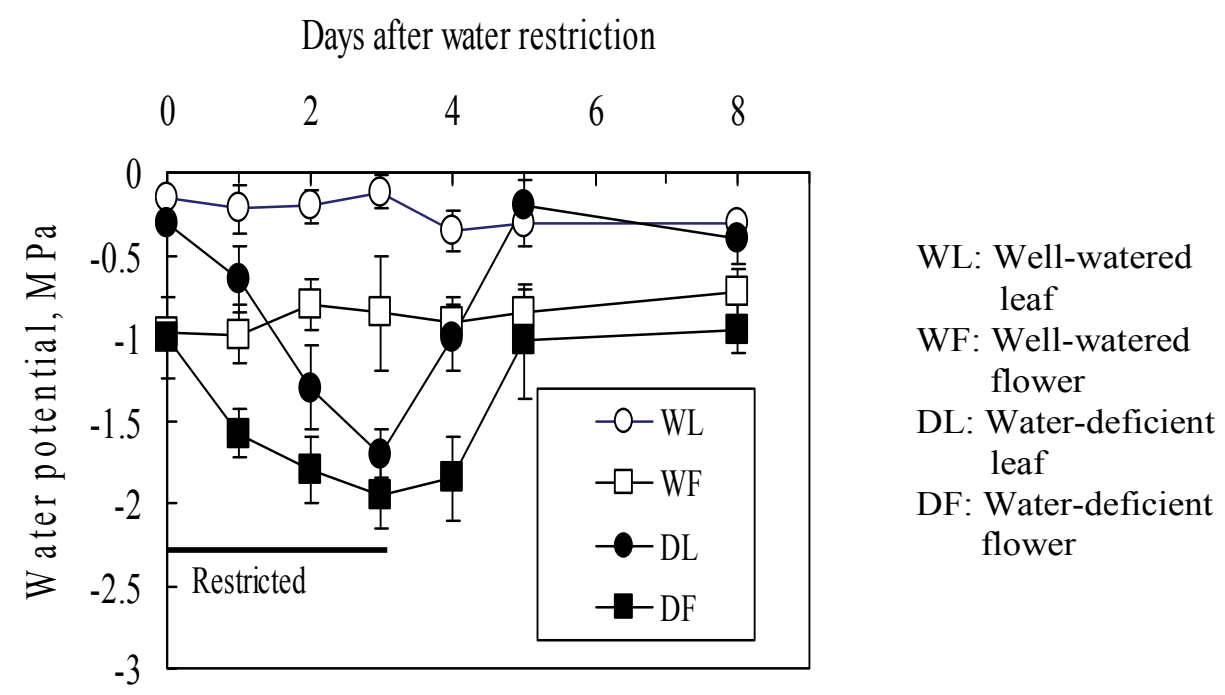

Fig. 8. Effect of water restriction on water potentials of leaves and flowers. From Kokubun et al. (2001).

No data describing the $\phi_{\mathrm{w}}$ of pollen and pistils had been available, likely due to the technical difficulty of making these measurements. We measured the $\phi_{\mathrm{w}}$ of whole flowers, and found that the flower $\phi_{\mathrm{w}}$ was always lower than the leaf $\phi_{w}$, by a difference of nearly $0.5 \mathrm{MPa}$. After a three-day water restriction, the $\phi_{\mathrm{w}}$ fell to $-1.7 \mathrm{MPa}$ in leaves and -2.0 MPa in flowers, respectively (Fig. 8). In maize, pollen $\phi_{\mathrm{w}}$ was generally found to be substantially lower than silk $\phi_{w}$, and silk $\phi_{\mathrm{w}}$ was found to vary with the water status of a plant, while pollen $\phi_{\mathrm{w}}$ did not (Westgate \& Boyer, 1986a). Because maize and soybean have different physiological characteristics and reproductive structures, evidence from maize may not hold true for soybean. However, it is noteworthy that pollen desiccation may not be a factor limiting kernel set in maize, because pollen does not lose viability at $\phi_{w}$ as low as $-12.5 \mathrm{MPa}$ (Westgate \& Boyer, 1986b). In our experiment, pollen which received severe water stress was still able to contribute to the development of a considerable number of pods, suggesting that pollen was not a limiting factor in pod set under water-stressed conditions.

It is difficult to identify directly whether pollen and/or pistils are relatively viable under water-stressed conditions. We indirectly evaluated their viability by measuring the pod-set percentages of flowers that were reciprocally crossed between well-watered and deficient plants (Kokubun et al., 2001). The pistils of well-watered plants, even when pollinated with pollen from water-deficient plants, were capable of initiating pods at a considerable rate, whereas water-deficient pistils developed few pods even when crossed with unstressed pollen. These results suggest that soybean flower abortion caused by a water deficit prior to anthesis is not attributable to an impairment of pollen function, but is more likely due to impairment of pistil function.

There have been few reports on the involvement of phytohormones in regulation of abortion under water-stressed conditions. Lie et al. (2003) found that reduced pod-set percentages induced by water deficit were associated with an increase in the ABA content of 
reproductive structures during a period from 3 to 5 days after anthesis. Because cytokinins play such a pivotal role in flower development, clarifying the interacting roles of cytokinins and other phytohormones, including ABA, will be the aim of future research.

\section{Conclusion and future research needs}

A large proportion of soybean flowers abort during development, a problem which is exacerbated by environmental stresses, particularly by water scarcity. This paper summarized the results of our recent studies, with an emphasis on 1) the involvement of phytohormones in the regulation of abortion (pod set), and 2) the differences in susceptibility of male and female organs to water stress during floral development.

Analyses of the concentrations of two endogenous hormones (cytokinin and auxin) and examination of the effects of their application on pod set have revealed that cytokinins have a positive, and auxin a negative effect, on pod set. Because the effects of application of synthetic cytokinins were unstable in field tests, the use of synthetic cytokinins as chemical enhancer of pod set in the field may be impractical. Genetic improvement of synthesis and transport of endogenous cytokinins from the root system, via conventional breeding or molecular approaches, may strengthen pod-set capacity of agriculturally significant genotypes. Clarification of the physical and chemical properties of the rhizosphere optimizing synthesis of endogenous cytokinins in roots should improve pod set.

Recent molecular and genomic analyses have facilitated the discovery of genes involved in regulating abiotic stresses, enabling genetic engineering using functional or regulatory genes to activate pathways involved in stress tolerance (Shinozaki-Yamaguchi et al., 2006). Of the genes that have been studied so far, DREB transgenes are known to impart tolerance to multiple stresses including chilling, heat, dehydration and salinity. Attempts to incorporate the Arabidopsis DREB genes, or homologs from other species, into crop species are currently underway. For example, transgenic rice plants overexpressing DREB1 have exhibited enhanced tolerance to drought. Similar attempts to incorporate these genes into soybean are being undertaken. Sequencing and analysis of a large collection of cDNA clones and subsequent clarification of genome sequence will build the molecular basis to accelerate the creation of novel soybean genotypes (Umezawa et al., 2008; Schmutz et al., 2010). Such recent advances have been magnificent, and we may soon be able to design ideal crops with multiple environmental stress tolerances.

\section{References}

Abernethy, R.H., Palmer, R.G., Shibles, R. \& Anderson, I.C. (1977). Histological observations on abscising and retained soybean flowers, Canadian Journal of Plant Science 57: 713716.

Antos, M. \& Wiebold, W.J. (1984). Abscission, total soluble sugars, and starch profiles within a soybean canopy, Agronomy Journal 76: 715-719.

Boyer, J.S. 1970. Leaf enlargement and metabolic rates in corn, soybean, and sunflower at various water potentials. Plant Physiology 46: 233-235.

Brevedan, R.E., Egli, D.B. \& Legget, J.E. (1978). Influence of N nutrition on flower and pod abortion and yield of soybeans, Agronomy Journal 70: 81-84.

Brun, W.A. \& Betts, K.J. (1984). Source/sink relations of abscising and nonabscising soybean flowers, Plant Physiology 75: 187-191. 
Carlson, D.R., Dyer, D.J., Cotterman, C.D. \& Durley, R.C. (1987). The physiological basis for cytokinin induced increases in pod set in IX93-100 soybean, Plant Physiology 84: 233239.

Carlson, J.B. \& Lesten, N.R. (1987). Reproductive morphology, in Wilcox, J.R. (ed.), Soybeans: improvement, production, and uses ( $2^{\text {nd }}$ ed.), ASA, CSSA, SSSA, Madison, WI, pp.95134

Cho, Y.K., Suh, S.K., Park, H.K. \& Wood, A. (2002). Impact of 2,4-D and BAP upon pod set and seed yield in soybean applied at reproductive stages. Plant Growth Regulation 36: $215-221$.

Crosby, K.E., Aung, L.H. \& Buss, G.R. (1981). Influence of 6-benzylaminopurine on fruit-set and seed development in two soybean, Glycine $\max$ (L.) Merr. genotypes, Plant Physiology 68:985-988.

Dybing, C.D., Ghiasi, H. \& Paech, C. (1986). Biochemical characterization of soybean ovary growth from anthesis to abscission of aborting ovaries, Plant Physiology 81: 10691074.

Dyer, D.J., Carlson, D.R., Cotterman, C.D., Sikorski, J.A. \& Ditson, S.L. (1987). Soybean pod set enhancement with synthetic cytokinin analogs, Plant Physiology 84: 240-243.

Emery, R.J.N., Leport, L., Barton, J.E., Turner, N.C. \& Atkins, C.A. (1998). Cis-isomers of cytokinins predominate in chickpea seeds throughout their development, Plant Physiology 117: 1515-1523.

Gai, J., Palmer, R.G. \& Fehr, W.R. (1984). Bloom and pod set in determinate and indeterminate soybeans in China, Agronomy Journal 76: 979-984.

Hansen, W.R. \& Shibles, R. (1978). Seasonal log of the flowering and podding activity of field-grown soybeans, Agronomy Journal 70: 47-50.

Heindl, J.C., Carlson, D.R., Brun, W.A. \& Brenner, M.L. (1982). Ontogenetic variation of four cytokinins in soybean root pressure exudates. Plant Physiology 70: 1619-1625.

Heindl, J.C. \& Brun, W.A. (1983). Light and shade effects on abscission and ${ }^{14} \mathrm{C}$ photoasimilate partitioning among reproductive structures in soybean, Plant Physiology 73: 434-439.

Heindl, J.C. \& Brun, W.A. (1984). Patterns of reproductive abscission, seed yield, and yield components in soybean, Crop Science 24: 542-545.

Huff, A. \& Dybing, C.D. (1980). Factors affecting shedding of flowers in soybean (Glycine $\max ($ L.) Merrill), Journal of Experimental Botany 31: 751-762.

Kato, I. \& Sakaguchi, S. (1954). Studies on the mechanism of occurrence of abortive grains and their prevention in soybeans, Glycine max M., Tokai-Kinki National Agricultural Experiment Station Bulletin 1: 115-132.

Kato, I., Sakaguchi, S. \& Naito, Y. (1955). Anatomical observations on fallen buds, flowers and pods of soybean, Glycine max M., Tokai-Kinki National Agricultural Experiment Station Bulletin 2: 159-168.

Kato, I. (1964). Histological and embryological studies on fallen flowers, pods and abortive seeds in soybean, Glycine max (L.), Tokai-Kinki National Agricultural Experiment Station Bulletin 11: 1-52.

Kokubun, M. (1988). Design and evaluation of soybean ideotypes, Bulletin of Tohoku National Agricultural Experiment Station 77: 77-142.

Kokubun, M. \& Honda, I. (2000). Intra-raceme variation in pod-set probability is associated with cytokinin content in soybeans, Plant Production Science 3: 354-359. 
Kokubun, M., Shimada, S. \& Takahashi, M. (2001). Flower abortion caused by preanthesis water deficit is not attributed to impairment of pollen in soybean, Crop Science 41: 1517-1521.

Kokubun, M. (2004). Mechanisms of flower abortion in water-stressed soybean, in Moscard, F. et al. (ed.), Proceedings of VII world soybean research conference, Embrapa, Londrina, PR, pp.253-259.

Liu, F.L., Anderson, M.N. \& Jenson, C.R. (2003). Loss of pod set caused by drought stress is associated with water stress and ABA content of reproductive structures in soybean. Functional Plant Biology 30: 271-280.

McGaw, B.A. \& Burch, L.R. (1995). Cytokinin biosynthesis and metabolism, in Davies, P.J. (ed.), Plant hormones, physiology, biochemistry, and molecular biology (2nd ed.), Kluwer Academic, Dordrecht, pp.98-117.

Mosjidis, C.O., Peterson, C.M., Truelove, B. \& Dute, R.R. (1993). Stimulation of pod and ovule growth of soybean, Glycine max (L.) Merr. by 6-benzylaminopurine, Annals of Botany 71: 193-199.

Nagel, L., Brewster, R., Riedell, W.E. \& Reese, R.N. (2001). Cytokinin regulation of flower and pod set in soybeans (Glycine max (L.) Merr.), Annals of Botany 88: 27-31.

Nonokawa, K., Kokubun, M., Nakajima, T., Nakamura, T. \& Yoshida, R. (2007). Roles of auxine and cytokinin in soybean pod setting, Plant Production Science 10: 199-206.

Oberholster, S.D., Peterson, C.M. \& Dute, R.R. (1991). Pedicel abscission of soybean: cytological and ultrastructural changes induced by auxine and ethephon, Canadian Journal of Botany 69: 2177-2186.

Peterson, C.M., Williams, J.C. \& Kuang, A. (1990). Increased pod set of determinate cultivars of soybean, Glycine max, with 6-benzylaminopurine, Botanical Gazetta 151: 322-330.

Prinsen, E., Kaminek, M. \& van Onckelen, H.A. (1997). Cytokinin biosynthesis: a black box? Journal of Plant Growth Regulation 23: 3-15.

Raper, C.D. Jr. \& Kramer, P.J. (1987). Stress physiology, in Wilcox, J.R. (ed.), Soybeans: improvement, production, and uses (2nd ed.), ASA, CSSA, SSSA, Madison, WI, pp.589641.

Reese, R.N., Dybing C.D., White, C.A., Page, S.M. \& Larson, J.E. (1995). Expression of vegetative storage protein (VSP- $\beta$ ) in soybean raceme tissues in response to flower set, Journal of Experimental Botany 46: 957-964.

Shaw, R.H. \& Laing, D.R. (1966). Moisture stress and plant response, in Pierre, W.H. et al. (ed.), Plant environment and efficient water use, American Society of Agronomy, Madison, pp.77-94.

Shibles, R.M., Anderson, I.C. \& Gibson, A.H. (1975). Soybean, in Evans, L.T. (ed.) Crop physiology, Cambridge University Press, London. pp. 151-189.

Shinozaki-Yamaguchi, K. \& Shinozaki, K. (2006). Transcriptional regulatory networks in cellular responses and tolerance to dehydration and cold stresses, Annual Review of Plant Biology 57: 781-803.

Schmutz, J., Cannon, S.B., Schlueter, J., Ma, J., Mitros, T., Nelson, W., Hyton, D.L., Song, Q., Thelen, J.J., Cheng, J., Xu, D., Hellsten, U., May, G.D., Yu, Y., Sakurai, T., Umezawa, T., Bhattacharyya, M.K., Sandhu, D., Valliyodan, B., Lindquist, E., Peto, M., Grant, D., Shu, S., Goodstein, D., Barry, K., Futrell-Griggs, M., Abernathy, B., Du, J., Tian, Z., Zhu, L., Gill, N., Joshi, T., Libault, M., Sethuraman, A., Zhang, X.C., Shinozaki, K., Nguyen, H.T., Wing, R.A., Cregan, P., Specht, J., Grimwood, J., Rokhsar, D., 
Stacey, G., Shoemaker, R.C. \& Jackson, S.A. (2010). Genome sequencing of the palaeopolyploid soybean, Nature 463: 178-183.

Sionit, N \& Kramer, P.J. (1977). Effect of water stress during different stages of growth of soybeans, Agronomy Journal 69: 274-278.

Sitton, D., Itai, C. \& Kende, H. (1967). Decreased cytokinin production in the roots as a factor in shoot senescence, Planta 73: 296-300.

Spollen, W.G., Wiebold, W.J. \& Glenn, D.S. (1986a). Intraraceme competition in field-grown soybean. Agronomy Journal 78: 280-283.

Spollen, W.G., Wiebold, W.J. \& Glenn, D.S. (1986b). Effect of intraraceme competition on carbon-14-labeled assimilate and abscisic acid in soybean. Crop Science 26: 12161219.

Umezawa, T., Sakurai, T., Totoki, Y. Toyoda, A., Seki, M., Ishiwata, A., Akiyama, K., Kurotani, A., Yoshida, T., Mochida, K., Kasuga, M., Tadaka, D., Maruyama, K., Nakashima, K., Enju, A., Mizukado, S., Ahmed, S., Yoshiwara, K., Harada, K., Tsubokura, Y., Hayashi, M., Sato, S., Anai, T., Ishimoto, M., Funatsuki, H., Teraishi, M., Osaki, M., Shinano, T., Akashi, R., Sakaki, Y., Yamaguchi-Sinozaki, K. \& Sinozaki, K. (2008). Sequencing and analysis of approximately 40000 soybean cDNA clones from a full-length-enriched cDNA library, DNA Research 15: 333-346.

Wareing, P.F., Khalifa, M.M. \& Treharne, K.J. (1968). Rate-limiting processes in photosynthesis at saturating light intensities, Nature 220: 453-457.

Westgate, M.E. \& Boyer, J.S. (1986a). Silk and pollen water potentials in maize, Crop Science 26: 947-951.

Westgate, M.E. \& Boyer, J.S. (1986b). Reproduction at low silk and pollen water potentials in maize, Crop Science 26: 951-956.

Westgate, M.E. \& Peterson, C.M. (1993). Flower and pod development in water-deficient soybeans (Glycine max L. Merr.), Journal of Experimental Botany 258: 109-117.

Wiebold, W.J., Ashley, D.A. \& Boerma, H.R. (1981). Reproductive abscission levels and pattern for eleven determinate soybean cultivars, Agronomy Journal 73: 43-46.

Wiebold, W.J (1990). Rescue of soybean flowers destined to abscise, Agronomy Journal 82: 8588.

Wiebold, W.J. \& Panciera, M.T. (1990). Vasculature of soybean racemes with altered intraraceme competition, Crop Science 30: 1089-1093.

Yashima, Y., Kaihatsu, A., Nakajima, T. \& Kokubun, M. (2005). Effects of source/sink ratio and cytokinin application on pod set in soybean, Plant Production Science 8: 139-144. 


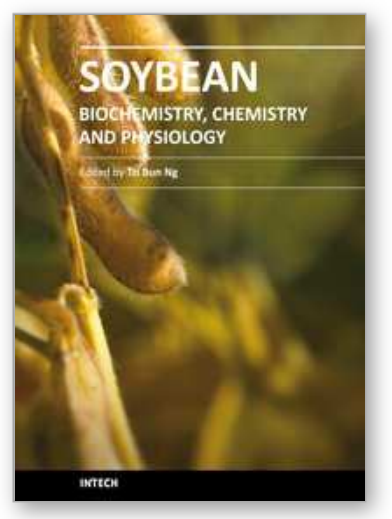

\section{Soybean - Biochemistry, Chemistry and Physiology \\ Edited by Prof. Tzi-Bun Ng}

ISBN 978-953-307-219-7

Hard cover, 642 pages

Publisher InTech

Published online 26, April, 2011

Published in print edition April, 2011

Soybean is an agricultural crop of tremendous economic importance. Soybean and food items derived from it form dietary components of numerous people, especially those living in the Orient. The health benefits of soybean have attracted the attention of nutritionists as well as common people.

\section{How to reference}

In order to correctly reference this scholarly work, feel free to copy and paste the following:

Makie Kokubun (2011). Physiological Mechanisms Regulating Flower Abortion in Soybean, Soybean Biochemistry, Chemistry and Physiology, Prof. Tzi-Bun Ng (Ed.), ISBN: 978-953-307-219-7, InTech, Available from: http://www.intechopen.com/books/soybean-biochemistry-chemistry-and-physiology/physiologicalmechanisms-regulating-flower-abortion-in-soybean

\section{INTECH}

open science | open minds

\section{InTech Europe}

University Campus STeP Ri

Slavka Krautzeka 83/A

51000 Rijeka, Croatia

Phone: +385 (51) 770447

Fax: +385 (51) 686166

www.intechopen.com

\section{InTech China}

Unit 405, Office Block, Hotel Equatorial Shanghai

No.65, Yan An Road (West), Shanghai, 200040, China 中国上海市延安西路65号上海国际贵都大饭店办公楼 405 单元

Phone: +86-21-62489820

Fax: $+86-21-62489821$ 
(C) 2011 The Author(s). Licensee IntechOpen. This chapter is distributed under the terms of the Creative Commons Attribution-NonCommercialShareAlike-3.0 License, which permits use, distribution and reproduction for non-commercial purposes, provided the original is properly cited and derivative works building on this content are distributed under the same license. 